Article

\title{
Investment Promotion, Fiscal Competition and Economic Growth Sustainability
}

\author{
Bin $\mathrm{Wu}^{*}$ (1), Xuefei Xu and Zhenzhong Feng \\ School of Economics and Management, Southeast University, Nanjing 210096, China; \\ 220151970@seu.edu.cn (X.X.); shooter1203@163.com (Z.F.) \\ * Correspondence: 101007032@seu.edu.cn
}

Received: 6 December 2017; Accepted: 23 December 2017; Published: 2 January 2018

\begin{abstract}
Local governments in China build development zones to attract investment. We develop a model of fiscal competition to examine investment promotion under centralization and decentralization. Our study shows that even when perfect information is not available, under the condition of an indivisible investment, a central government achieves the optimal investment in development zones and the best tax ratio for maximizing total welfare, whereas decentralized decision-making easily results in infrastructure overinvestment and tax erosion, which does harm to economic growth sustainability.
\end{abstract}

Keywords: fiscal competition; investment promotion; economic growth sustainability

\section{Introduction}

China's fiscal decentralization reform and tax sharing system [1] gives local government officials the ability to pursue economic growth in their region; this local economic development, pursued by officials who are competing for political promotions, is seen as one of major engines of China's economic growth $[2,3]$. This is consistent with the endogenous economic growth model proposed by Hatfield [4], which suggests that inter-jurisdictional competition drives policymakers in a decentralized government to choose tax policies that maximize economic growth.

As attracting investment is seen as one of the most important factors in economic growth, local governments have fiscal incentives to compete for outside capital [5,6]. Local governments usually establish investment promotion bureaus to encourage investors to build companies in local jurisdictions and to create suitable economic development zones [7]. As development zones are often managed in a top-down way [8], local governments can offer firms in these development zones favorable policies and government support. Commonly, governments spend huge amounts on infrastructure in these zones, and firms with new capital have access to preferential tax policies and to land for development and business use [9].

In the process of attracting outside capital, local authorities trade infrastructure expenditure and short-term tax losses from their low tax-rate preferential policies for long-term sustainable tax revenue and employment opportunities. The evidence suggests that such policies often improve economic growth and local welfare. Wang's [10] study of economic development zones finds that such place-based programs improve local economies by increasing foreign and domestic direct investment, total factor productivity growth, and factor prices. Recent studies also show that development zones have spillover effects [11]. A similar pattern has been found in other countries. Mayer et al. [12] demonstrate the positive and sizable effect of the French enterprise zone program on location decisions in the Zones "Franches Urbaines" (ZFU), and Briant et al. [13] indicate that such programs create jobs in spatially integrated neighborhoods, especially for low-wage workers. Neumark and Kolko [14] and Kline and Moretti [15] also obtained similar results in studies of California and Tennessee in the US.

In economic development zones, preferential tax policies and infrastructure expenditure are two critical methods commonly used by local jurisdictional governments to attract capital to establish 
new business. However, the preferential tax policies used by local governments to attract capital investment can easily exacerbate local tax mimicking and inefficient horizontal tax competition. In the competition to attract mobile capital (a tax base), local governments engage in a "race to the bottom" tax-rate competition. Unlike in the standard tax competition discussed in Wilson [16] and Zodrow and Mieszkowski [17], local tax rates in China are set by the central government, but local governments have discretion in tax enforcement and can offer preferential tax policies (e.g., tax concessions and tax rebates), which are crucial elements in the tax management process as they affect the level and distribution of effective tax rates across regions [18-20]. In addition, the management of enforcement strategies, such as allowing tax avoidance [21,22], can also be used as a competition tool. Many studies have confirmed that competition between local jurisdictions affects tax policies in China, especially in economic development zones $[5,9,23]$.

In fact, local governments in other countries, especially countries with fiscal federalism, also engage in tax competition to attract capital. In the United States, Crowley and Sobel [24] applied spatial econometric methods to panel data from Pennsylvania and find that fiscal decentralization results in stronger intergovernmental competition and lower tax rates. In Spain, Delgado et al. [25] used cross-sectional data from a sample of Spanish municipalities and find tax mimicking among local governments, which can be seen as a strategic interaction of local tax choices. In Germany, Buettner and von Schwerin [26] examined how tax rate policy interdependence affects the local business tax rate in the German federation. Li's [20] empirical analysis of data from 50 developing countries showed that fiscal decentralization allows local governments to offer preferential tax policies and decreases efficiency due to tax competition.

Similarly, countries compete to attract foreign direct investment. Multinational firms choose locations according to tax rates, leading countries to offer competitive corporate tax rates. Such competition can explain the drop in statutory tax rates in 21 Organization for Economic Co-operation and Development (OECD) countries [27]. Similar tax competition exists between European Union countries [28]. Altshuler and Goodspeed [29] found evidence that national governments compete with other national governments using the case that the USA Tax Reform Act of 1986 led to tax reforms in European countries.

Although tax reductions are a common strategy for attracting new firms, infrastructure projects undertaken to enhance firms' locations are also an important draw for newcomers [30]. In China, more and more local governments are investing huge fiscal funds in infrastructure projects in development zones. Jia et al. [31] used a large country-level fiscal dataset for the 1997 to 2006 period to examine fund allocation in China and found that over that period governments spent more on capital construction but less on education and administration. A negative outcome of this trend is that some zones have too many firms whereas others are empty, a pattern that has been called the "economic development zone fever" [32-34]. Similar phenomena have occurred in many countries, such as the overprovision of business areas in Europe [35] and under-occupied industrial parks in Japan [36].

However, competition between local authorities to attract high-quality investment through preferential taxes and better public service has been so fierce that it has incurred infrastructure overinvestment and excessive tax credits for foreign investors. The race-to-the-bottom tax-rate competition has pushed the equilibrium tax rate far below the optimal level and decreased social welfare [37]. If future tax revenue is low due to the under-occupation of the development zones, it does not pay for the infrastructure investment and the local authorities' development activities are a waste of resources. In China, some theoretical and empirical studies have noted that "economic development zone fever" has led to the loss of agricultural land and low land-use efficiency in development zones [38]. Yu et al. [23] argue that the formation of enterprise zones is the result not of local economic status, but of yardstick competition created across local governments, and can easily result in a waste of public resources. Jimenez [39] believes that intergovernmental tax competition becomes vicious and forces local governments to focus their spending on development and economic growth, instead of redistributive services, thus decreasing residents' welfare. 
Our tax competition model includes several characteristics of development zones that are neglected in previous studies. First, we consider enterprise investment as indivisible. Under this condition, an investor can choose only one of the alternative zones to establish a new business. A similar condition exists in King et al. [40] and Jayet and Paty [41]. Second, a local government has two target values: (1) the income that citizens will get from the new factory, and (2) the utility of investors. The cost of the infrastructure projects is deducted from the welfare that ordinary citizens would get without the investment, and it is a sunk cost for site promotion. Similar conditions exist in Hatfield [4] and Philipowski [42].

Many studies confirm the existence of interjurisdictional tax competition and the undesirable results of "economic development zone fever"; however, most present only the empirical evidence and do not offer theoretical models to explain the phenomenon. We consider investment promotion as a process in a model of standard fiscal competition, where a government can attract new-entry mobile capital to establish new business by providing outside investors with preferential tax policies. We further consider public infrastructure competition and give a theoretical model of the overinvestment that characterizes "economic development zone fever". Our tax competition model uses mathematic computation, which considers the decision-making of local governments and the central government and they have the same aim to find the optimal tax levels and infrastructure investments that maximize total welfare. In addition, we compare two opposite situations: whether governments have adequate information or not. The model's implications are important for developing countries seeking to manage capital investments.

The rest of this paper is organized as follows. In Section 2, we introduce the main hypothesis and our model. In Section 3, our model analyzes decision-making regarding tax policy and economic development zones under decentralized and centralized government administrative systems. In Section 4, we analyze infrastructure investment competition in economic development zones for a given number of development zones and tax rates. In Section 5, we present our conclusions. We present all of the proofs in Appendix A.1.

\section{Model of Tax Competition}

\subsection{Main Assumptions}

Our basic assumptions derives from Jayet and Paty [41], who argue that the excessive provision of economic development zones leads to too many business areas, some of which will be empty. In this study, we focus on tax policies under fiscally centralized and decentralized government systems and the wasted infrastructure investment in economic development zones by local governments. Our basic model makes the following assumptions (see Appendix A.4 for variable definitions).

(1) A representative country has $M$ local governments at the same level and one central government. There is no vertical tax competition between local governments and the central government. An $N$ number of the $M$ zones are development zones.

(2) Local governments take part in tax competition by cutting taxes or investing in infrastructure. All of these governments take these actions at the same time.

(3) The governments collecting revenue abide by the principle of territorial jurisdiction. They do not impose tax on investments in other zones with capital from local zones.

(4) All of the investments receive identical marginal revenue. We assume that the marginal revenue of investors is enough that the investment can bear the cost difference generated by distance even if two potential investment locations are distant from each other.

(5) Labor has little fluidity, but each labor force has the same marginal output. Therefore, the costs of labor for the site investors are always the same.

(6) Site investors have two kinds of returns. The type from regular operations is explicit and related to the investments in the operation. The other type of return is implicit and related to the resource endowments of the zone in which the new factory is located. 
(7) If zone $i$ is chosen as the location for the new investment, the government of zone $i$ imposes a tax ratio of $\theta_{i}$ on the total income of the new factory. The central government decides whether to give the local governments the right to make decisions about taxes, and determines the tax-sharing rate between the local government and itself. The local government has to turn over $\gamma_{i}$ of the zone tax revenue to the central government. We neglect the transfer payment of the central government to any development zone.

\subsection{Construction of Tax Competition Model}

There are two factors in the production process: labor and capital. An investor invests capital into a chosen location and local citizens provide labor. Suppose the enterprise has chosen zone $i$ to invest. According to Jayet and Paty [41], the total income would be described as follows:

$$
R_{i}=\left(A \cdot l^{\alpha} \cdot K^{1-\alpha}-w \cdot l\right)+u \cdot\left(\varepsilon_{i}+x_{i}\right)
$$

The $\left(A \cdot l^{\alpha} \cdot K^{1-\alpha}-w \cdot l\right)$ in the right-hand side of Equation (1) represents the dominant return $R$ enterprises generate from the daily operation. $A \cdot l^{\alpha} \cdot K^{1-\alpha}$ represents the Cobb-Douglas production function. $K$ denotes the amount of capital enterprise invested in the operation. Let $l$ be the best labor a site investor would hire and $w$ be the best wage the investor would offer. $u$ represents the influence of compatibility between the type of enterprise investment and the infrastructure environment in the development zone on the enterprise's earning capability. $\varepsilon_{i}$ represents the compatibility between the type of enterprise investment and the infrastructure environment in the development zone. To simplify our analysis, we let $\varepsilon_{i}$ follow an exponential distribution. The $x_{i}$ in the right-hand side of (1) denotes the amount of improvement of the infrastructure environment resulting from government infrastructure investment $C_{i} . C_{i}$ is obviously a sunk cost of zone development, so we get $\frac{\partial x_{i}}{\partial C_{i}}>0, \frac{\partial^{2} x_{i}}{\partial C_{i}}>0$. The enterprise has the opportunity to build a factory outside the available development zones, and the value of the certain outside opportunity is $\rho \geq 0$ (i.e., in no case would the enterprise suffer a loss). There are several alternatives to building in a development zone: not building a new factory, building a factory outside a development zone, or building a factory in a foreign country. This creates a bigger multistage location competition.

Hence, the local citizens' welfare could be described as

$$
\Delta w+R \cdot \theta,
$$

where $\Delta w=L \cdot w(L)-\int_{0}^{L} w(l) d l$ is the net return of working labor from the new factory. The $\theta$ in the term denotes the net tax ratio that the government imposes on the income of the new factory operation. When the net $\operatorname{tax}$ ratio $\theta$ is negative, it represents a subsidy that the government is offering to attract new investment. If the site investor has adequate information about $u, \varepsilon, x$, and $\theta$, he or she will choose the zone that offers him or her the maximum return. The following lemma describes such a choice.

Lemma 1. If a subset of $N$ sites is developed and $\theta=\left(\theta_{i}\right)_{i \in N}$ are the tax rates of these sites, then the probability of the firm choosing site $i$ is

$$
P_{i}(x, \theta, N)=\frac{1}{\lambda^{N-1}} e^{-\lambda\left[-2\left(z_{i}+x_{i}\right)+\sum_{i \neq j}\left(z_{j}+x_{j}\right)+\frac{\rho}{u}\right]}, z_{i}=\frac{1-\theta_{i}}{u}, i \in N
$$

and the probability of the firm taking an outside opportunity is

$$
P_{0}(x, \theta, N)=\prod_{i=1}^{N}\left[1-e^{-\lambda\left(\frac{\rho}{u}-z_{i}-x_{i}\right)}\right],
$$

where $\rho$ is the outside opportunity and $\rho \geq 0$. 
Proof. See Appendix A.1.

\section{Choice of Tax Policy}

\subsection{Central Government's Choice of Tax Policy}

In this section, we assume that $N$ development zones are built and that all of these $N$ development zones are managed by one central government, which pursues the maximum total welfare of the country. The sequence of actions is as follows.

(1) The central planner proposes all of the developed sites to the firm, announcing a tax level or subsidy level for each of them, producing a vector of tax levels $\theta=\left(\theta_{i}, \theta_{-i}\right)$. This announcement is a commitment. The planner cannot modify the tax level in the following steps.

(2) The site investor analyses the environment of every site and chooses the location of the new plant according to the information available.

(3) The new plant hires workers, begins production, and pays wages and taxes.

The central planner maximizes welfare by determining the best vector of tax (or subsidy) levels $\theta=\left(\theta_{i}, \theta_{-i}\right)$ based on detailed information about the environment of every site. However, the central government does not always have adequate information for such decision-making.

\subsubsection{Central Government's Choice of Tax Policy with Adequate Information}

If the central planner has enough information about $\varepsilon_{i}$, and the new investment is indivisible, it can offer the new investor the zone with the maximum $\varepsilon$. Let $\varepsilon_{i}=\max \left\{\varepsilon_{1}, \varepsilon_{2}, \ldots \ldots, \varepsilon_{M}\right\}$. Then, when zone $i$ has the maximum welfare, the total welfare level is maximized. That is, $\varepsilon_{i}=\max \left\{\varepsilon_{1}, \varepsilon_{2}, \ldots \ldots, \varepsilon_{M}\right\}$. Hence, $\max E(V) \Leftrightarrow \max E\left(V_{i}\right)$.

$$
\begin{gathered}
\max E(V)=P\left\{R \cdot\left(1-\theta_{i}\right)+u \cdot\left(\varepsilon_{i}+x_{i}\right) \geq \rho\right\} \cdot\left(\Delta w+R \cdot \theta_{i}\right)-C_{i} \\
=\left(\Delta w+R \cdot \theta_{i}\right) \cdot e^{-\lambda\left(\frac{\rho}{u}-z_{i}-x_{i}\right)}
\end{gathered}
$$

When $\frac{\partial E\left(V_{i}\right)}{\partial \theta_{i}}=0$ in Equation (3), we get $\theta^{*}=\frac{u}{\lambda \cdot R}-\frac{\Delta w}{R}$.

Proposition 1. When the central government has adequate information about every site, it can provide zone $i$, $\varepsilon_{i}=\max \left\{\varepsilon_{1}, \varepsilon_{2}, \ldots \ldots, \varepsilon_{M}\right\}$, as the only choice for the firm, and offer a tax level of $\theta^{*}=\frac{u}{\lambda \cdot R}-\frac{w}{R}$ to the new investor to maximize the total welfare.

\subsubsection{Central Government's Choice of Tax Policy without Adequate Information}

When the central government knows only the distribution of $\varepsilon$, it can only offer all of its development zones to the new investor. Therefore, the central planner can only get the best welfare level as follows:

$$
\max E(\Delta V)=\sum_{i=1}^{N}\left\{P_{i} \cdot\left(\Delta w_{i}+R_{i} \cdot \theta_{i}\right)-C_{i}\right\} .
$$

With the help of Lemma 1, we get Proposition 2.

Proposition 2. When the central government has inadequate information, its best vector of tax levels is $\theta^{0}=\left(\theta_{i}^{0}\right)_{i \in N}$ and the best vector of environment change indexes is $x^{0}=\left(x_{i}^{0}\right)_{i \in N^{\prime}}$ where $\theta, x$ satisfy the condition of

$$
\left[a \cdot e^{-3 \lambda\left(\frac{u}{R}\right)}-\left(3 w_{i}+\lambda u\right)\right] \cdot\left[a \cdot e^{-3 \lambda x_{i}}-\left(3 w_{i}+3 R+3 \lambda u\right)\right] \leq 0,(i \in N)
$$


Proof. See Appendix A.2.

In fact, we can determine the best infrastructure investment levels $C^{0}=\left(C_{i}^{0}\right)_{i \in N}$ from the vector of environment change indexes $x^{0}=\left(x_{i}^{0}\right)_{i \in N}$.

\subsection{Local Governments' Choices of Tax Policy under Decentralization}

When the right to make development decisions is decentralized, local governments can make their own choices about infrastructure investment and tax levels. Both of these choices should satisfy the conditions described in Proposition 2 for the central government. Therefore, the government of zone $i$ would choose the tax rate $\theta$ that maximizes

$$
E\left(\Delta V_{i}(N, U, \theta)\right)=P_{i}\left(\Delta w_{i}+R \cdot \theta_{i} \cdot r_{1}\right)-C_{i}
$$

In Equation (8), when $\frac{\partial E(\Delta V)}{\partial \theta_{i}}=0$, we get

$$
\theta_{i}^{e}=\frac{u}{2 \cdot \lambda \cdot R}-\frac{\Delta w}{R \cdot r_{1}}
$$

Proposition 3. When a local government has the right to make its own decisions, if its tax level and infrastructure investment level satisfy the condition in Proposition 2, there is a balanced vector of tax levels: $\theta^{e}=\left(\theta_{i}^{e}\right)_{i \in N^{\prime}} ; \theta_{i}^{e}=\frac{u}{2 \cdot \lambda \cdot R}-\frac{w_{i}}{R \cdot r_{1}}$.

Proof. See Appendix A.3.

A comparison of the results of centralized and decentralized decision making, given $E(V)-E\left(V_{i}\right)=\sum_{i=1}^{N} P_{i}\left[\Delta w_{i}+R \cdot \theta_{i} \cdot\left(1-r_{1}\right)-C_{i}\right]$, suggests that the expected return on infrastructure investment and tax competition is positive (or the local government does not decide to join the game). Hence,

$$
\begin{aligned}
\frac{\partial E(V)}{\partial \theta_{i}}-\frac{\partial E\left(V_{i}\right)}{\partial \theta_{i}} & =\frac{\partial P_{i}}{\partial \theta_{i}} \cdot\left(\Delta w_{i}+R \cdot \theta_{i}\right)+\sum_{i \neq j} \frac{\partial P_{i}}{\partial \theta_{i}} \cdot\left(\Delta w_{j}+R \cdot \theta_{j}\right)+P_{i} \cdot R \\
& -\left\{\frac{\partial P_{i}}{\partial \theta_{i}} \cdot\left(\Delta w_{i}+R \cdot \theta_{i}\right) \cdot r_{1}+P_{i} \cdot R \cdot r_{1}\right\} \\
& =\frac{\partial P_{i}}{\partial \theta_{i}} \cdot R \cdot \theta_{i} \cdot\left(1-r_{1}\right)+\sum_{i \neq j} \frac{\partial P_{i}}{\partial \theta_{i}}\left(\Delta w_{j}+R \cdot \theta_{j}\right)+P_{i} \cdot R \cdot r_{1}>0
\end{aligned}
$$

Thus, local welfare is more sensitive to tax levels than total welfare.

As $\theta_{i}^{0}=\frac{a}{3 R} \cdot e^{3 \lambda\left(z_{i}+x_{i}\right)}-\frac{\lambda u}{3 R}$ and $\theta^{e}=\frac{u}{2 R \lambda}-\frac{\Delta w_{i}}{R \cdot r_{1}}$, then according to the preceding analysis we get Proposition 4.

Proposition 4. Decentralized governments are more likely to offer preferential taxes and to invest in local infrastructure.

We further assume that the number of zones offered by local governments to the site investor is $N^{e}$ under decentralization. Let $\bar{N}$ be the number of development zones when the total investment in infrastructure can be compensated for by the expected return. As local governments rarely make the same decisions as central planners, $\bar{N} \geq N^{0}$ and $\theta_{i}^{0}>\theta_{i}^{e}$. Therefore, $\theta_{i}^{0} \cdot R>\theta_{i}^{e} \cdot R$, and we find that decentralization brings less welfare to the country than centralization.

Therefore, it is easy to conclude that when the central planner has adequate information to make decisions, the country will always get the best output. However, it is not easy for the central government to obtain adequate information, especially when there are many levels of government. Furthermore, obtaining such information would be costly. 
From the perspective of local governments, the expected return should satisfy $E\left(\Delta V_{i}\right)>0$, or they would not provide the firm with the site. As $P_{i} \cdot\left(\Delta w_{i}+R \cdot \theta_{i}\right) \cdot r_{1}-C_{i}>0$, we obtain $R \cdot \theta_{i} \geq \frac{C_{i}}{r_{1} \cdot P_{i}}-\Delta w_{i}$.

As $\frac{\partial \theta_{i}}{\partial N}<0$, when $N=\bar{N}$, we get $R \cdot \theta_{i}=\frac{C_{i}}{r_{1} \cdot P_{i}}-\Delta w_{i}$.

Proposition 5. When decentralization and the expected return satisfy the condition $E\left(V_{i}\right)>0$, a local government will have the motivation to invest in infrastructure to increase the probability of being chosen. However, citizens' welfare is not necessarily increased by such investment.

\section{Infrastructure Investment Decisions under Decentralization}

In this section, we assume that $N$ of the zones are allowed to be developed as economic development zones and that the best vector for the tax level $\theta^{0}=\left(\theta_{i}^{0}\right)_{i \in N}$ is decided by the central government. We concentrate on how much the local government invests in infrastructure when the number of development zones and the vector of tax levels are fixed by the central government.

\subsection{Investment with Adequate Information}

For local governments, adequate information means that the amount of investments in infrastructure is known by all of the governments before the site investor makes a decision. Any $x_{i}=\left(x_{i}\right)_{i \in N}$ is public knowledge. Therefore, the first order condition for maximizing local welfare is

$$
\frac{\partial E\left(V_{i}\right)}{\partial C_{i}}=R \cdot r_{1} \cdot P_{i} \cdot \frac{\partial \theta_{i}^{0}}{\partial x_{i}} \cdot \frac{\partial x_{i}}{\partial C_{i}}+\left(w_{i}+R \cdot r_{1} \cdot \theta_{i}^{0}\right) \cdot \frac{\partial P_{i}}{\partial x_{i}} \cdot \frac{\partial x_{i}}{\partial C_{i}}=0 .
$$

Hence, we get $2\left(\Delta w_{i}+R \cdot r_{1} \cdot \theta_{i}^{0}\right) \frac{\partial x_{i}}{\partial C_{i}}+\frac{a \cdot r_{1}}{3} \frac{\partial x_{i}}{\partial C_{i}}=\lambda^{N-2} \cdot e^{\lambda\left[-2\left(z_{i}+x_{i}\right)+\sum_{i \neq j}\left(z_{j}+x_{j}\right)+\frac{\rho}{u}\right]}$.

To simplify the analysis, we assume $\frac{\partial x_{i}}{\partial C_{i}}=b<1$ in (8); therefore,

$$
C_{i}^{e}=\frac{-1}{2 b \lambda} \cdot \ln \xi\left(\theta_{i}^{0}, r_{1}\right)+\frac{1}{2 b} \sum_{i \neq j}\left(z_{j}+x_{j}\right)+\frac{\rho}{2 b u}-\frac{z_{j}}{b}+\widetilde{c}
$$

where $\xi\left(\theta_{i}^{0}, r_{1}\right)=\left[6 b\left(\Delta w_{i}+R \cdot r_{1} \cdot \theta_{i}^{0}\right)+2 a b r_{1}\right] /\left[3 \lambda^{N-2}\right]$.

This leads to the following proposition.

Proposition 6. When the infrastructure investment information is symmetrical, there may be a condition $\frac{\partial E\left(V_{i}\right)}{\partial C_{i}}=R \cdot r_{1} \cdot P_{i} \cdot \frac{\partial \theta_{i}^{0}}{\partial x_{i}} \cdot \frac{\partial x_{i}}{\partial C_{i}}+\left(w_{i}+R \cdot r_{1} \cdot \theta_{i}^{0}\right) \cdot \frac{\partial P_{i}}{\partial x_{i}} \cdot \frac{\partial x_{i}}{\partial C_{i}}=0$ that obtains the infrastructure investment level at which the local government maximizes local welfare.

\subsection{Investment under Inadequate Information}

Under the inadequate information condition, any $x_{i}=\left(x_{i}\right)_{i \in N}$ is only known by zone $i$. Therefore, $P_{i}$ is very valuable in such decision-making.

As $\frac{\partial P_{i}}{\partial C_{i}}>0$, when $P_{i} \cdot\left(\Delta w_{i}+R \cdot \theta_{i} \cdot r_{1}\right)-C_{i} \geq 0$ is satisfied, government $i$ will invest in infrastructure to attract new investment. Obviously, if $\frac{\partial P_{i}}{\partial C_{j}}<0$ and $\frac{\partial E_{i}}{\partial C_{j}}=\left(\Delta w_{i}+R \cdot \theta_{i} \cdot r_{1}\right) \cdot \frac{\partial P_{i}}{\partial C_{j}}<0$, the governments of the $N$ development zones will soon find themselves trapped in serious competition to increase infrastructure investment until the marginal return becomes zero and $P_{i} \cdot\left(\Delta w_{i}+R \cdot \theta_{i}\right)-C_{i}=0$. If a local government does not have an accurate estimate of this margin, future revenue will not compensate for this investment, even if the firm locates to this zone, as the developing expense, $C_{i}$, is related to factors such as the resources in zone $i$. 


\section{Conclusions}

We developed a model of fiscal competition between local jurisdictions to examine the investment promotion of economic development zones, and used the model to examine tax rate policies under centralization and decentralization. For a given tax rate, we further analyze the effects of competition on decisions to invest in infrastructure in economic development zones. Our analysis lead to several interesting conclusions.

When a central government is considering an indivisible investment and has adequate information, it will always be able to find the tax levels, subsidy levels, and infrastructure investments that maximize total welfare. Furthermore, when all of the jurisdictions in a country are treated as a single economic development zone, enterprise location becomes a game between the enterprise and central government, in which all of the local governments cooperate.

As the sensitivity of the tax rate to infrastructure investment varies between zones, decentralized local governments are more apt to offer unprofitable preferential taxes to new site investors at any cost. Assuming a fixed marginal revenue and perfect competition, the horizontal tax competition between decentralized local governments to attract liquid capital investment will result in an equilibrium tax rate lower than the Pareto-optimal tax rate.

Given a fixed number of development zones and fixed tax rates, local governments can easily substitute infrastructure investment competition for tax rate competition. With adequate investment information, local governments can determine the investment level that increases the probability of being chosen. However, such investments do not increase citizens' welfare. With inadequate infrastructure investment information, the outcomes may be even more discouraging. Overinvestment in site infrastructure wastes fiscal funds, reducing funds available for public services and worsening economic growth sustainability. These conclusions are consistent with those in Aslim and Neyapti [43]. However, our analysis does not take the costs that governments spend after firms locate into consideration, which can be a future progress of our research.

According to our research conclusion from Section 3, the central government can set a better tax rate and development zone policies than local governments. In addition, the amount of investment in infrastructure is not usually known by all of the governments before the site investor makes a decision, which means that development zones are easily trapped in serious competition and resources waste according to our research conclusion from Section 4. Policy-makers should consider the bad result of tax competition on investment promotion when they achieve short-term economic growth goals relying on attracting investment. Chinese authorities indeed recognize that fiscal federalism has resulted in unregulated fiscal competition between local governments building development zones and offering preferential tax policies. They halted the establishment of new economic development zones in 2006 and introduced a new policy in 2014 to regulate the tax preferential policies offered by local governments. Although these two policies were stopped because of strong opposition from local governments and foreign capital, we believe they suppress inter-jurisdictional horizontal competition, which is efficient for long-term economic growth sustainability.

Acknowledgments: This research was supported by the National Social Science Foundation of China (No. 16BJY154) and the Special Fund for basic research business of Southeast University in 2017 (No. 2242017S10032: 3214007113).

Author Contributions: Bin Wu had the idea and conceived the concept of the article; Xuefei Xu and Zhenzhong Feng are responsible for the model building and overall writing process.

Conflicts of Interest: The authors declare no conflict of interest. 


\section{Appendix A}

\section{Appendix A.1. Proof of Lemma 1}

Suppose an enterprise has invested in zone $i$, so

$$
R\left(1-\theta_{i}\right)+u\left(\varepsilon_{i}+x_{i}\right) \geq R\left(1-\theta_{j}\right)+u\left(\varepsilon_{j}+x_{j}\right), j \in N, i \neq j .
$$

For $\forall j \in N, j \neq i$ there are

$$
\begin{gathered}
\mathrm{P}\left\{R\left(1-\theta_{i}\right)+u\left(\varepsilon_{i}+x_{i}\right) \geq R\left(1-\theta_{j}\right)+u\left(\varepsilon_{j}+x_{j}\right)\right\}=\mathrm{P}\left\{\varepsilon_{i}-\varepsilon_{j} \geq z_{j}-z_{i}+x_{i}-x_{j}\right\}= \\
\int_{0}^{+\infty} \int_{\varepsilon_{j}+z_{j}-z_{i}+x_{i}-x_{j}}^{+\infty} \lambda e^{-\lambda \varepsilon} d \varepsilon_{i} d \varepsilon_{j}=\frac{1}{\lambda} e^{-\lambda\left(z_{j}-z_{i}+x_{i}-x_{j}\right)} .
\end{gathered}
$$

Obviously, the analysis of different zones is mutually independent, so

$$
\begin{gathered}
P_{i}(x, \theta, N)=\left[\prod_{i=1}^{N} e^{-\lambda\left(z_{j}-z_{i}+x_{i}-x_{j}\right)}\right] \cdot \mathrm{P}\left\{R\left(1-\theta_{i}\right)+u\left(\varepsilon_{i}+x_{i}\right) \geq \rho\right\}= \\
\frac{1}{\lambda^{N-1}} e^{-\lambda\left[-x_{i}-z_{i}+\sum_{j \neq i}\left(z_{j}+x_{j}\right)\right]} \cdot e^{-\lambda\left(-x_{i}-z_{i}+\frac{\rho}{u}\right)}=\frac{1}{\lambda^{N-1}} e^{-\lambda\left[-2\left(z_{i}+x_{i}\right)+\sum_{i \neq j}\left(z_{j}+x_{j}\right)+\frac{\rho}{u}\right]},
\end{gathered}
$$

which is Equation (3).

Appendix A.2. Proof of Proposition 2

$$
\begin{gathered}
E(V)=\sum_{i=1}^{N} P_{i} \cdot\left[\left(\Delta w_{i}+R_{i} \cdot \theta_{i}\right)-C_{i}\right] \\
\frac{\partial E(V)}{\partial \theta_{i}}=\frac{\partial P_{i}}{\partial \theta_{i}} \cdot\left(\Delta w_{i}+R \cdot \theta_{i}\right)+\sum_{i \neq j} \frac{\partial P_{j}}{\partial \theta_{i}} \cdot\left(\Delta w_{j}+R \cdot \theta_{j}\right)+P_{i} \cdot R=0
\end{gathered}
$$

where

$$
\frac{\partial P_{i}}{\partial \theta_{i}}=\frac{-2 R}{u \cdot \lambda^{N-2}} \cdot e^{-\lambda\left[-2\left(z_{i}+x_{i}\right)+\sum_{j \neq i}\left(\Delta w_{j}+R \cdot \theta_{j}\right)+\frac{\rho}{u}\right]}
$$

and

$$
\frac{\partial P_{j}}{\partial \theta_{i}}=\frac{R}{u \cdot \lambda^{N-2}} e^{-\lambda\left[-2\left(z_{i}+x_{i}\right)+\sum_{j \neq i}\left(z_{j}+x_{j}\right)+\frac{\rho}{u}\right]},
$$

so

$$
\begin{gathered}
\frac{\partial E(V)}{\partial \theta_{i}}=0 \\
\Rightarrow\left(\Delta w_{i}+R \cdot \theta_{i}\right) \quad \cdot \frac{-3 R}{u \cdot \lambda^{N-2}} \cdot e^{-\lambda\left[-2\left(z_{i}+x_{i}\right)+\sum_{j \neq i}\left(\Delta w_{j}+R \cdot \theta_{j}\right)+\frac{\rho}{u}\right]} \\
+\sum_{j=1}^{N}\left(\Delta w_{j}+R \cdot \theta_{j}\right) \cdot \frac{R}{u \cdot \lambda^{N-2}} \cdot e^{-\lambda\left[-2\left(z_{i}+x_{i}\right)+\sum_{j \neq i}\left(z_{j}+x_{j}\right)+\frac{\rho}{u}\right]} \\
+\frac{R}{\lambda^{N-1}} e^{-\lambda\left[-2\left(z_{i}+x_{i}\right)+\sum_{j \neq i}\left(z_{j}+x_{j}\right)+\frac{\rho}{u}\right]}=0 \\
\Rightarrow\left[-3 \cdot\left(\Delta w_{i}+R \theta_{i}\right)+\lambda u\right] \cdot e^{3 \lambda\left(z_{i}+x_{i}\right)}+\sum_{j=1}^{N}\left(\Delta w_{j}+R \theta_{j}\right) \cdot e^{-3 \lambda\left(z_{j}+x_{j}\right)}=0 \\
\Rightarrow\left[3 \cdot\left(\Delta w_{i}+R \theta_{i}\right)+\lambda u\right] \cdot e^{-3 \lambda\left(z_{i}+x_{i}\right)}=\sum_{j=1}^{N}\left(\Delta w_{j}+R \theta_{j}\right) \cdot e^{-3 \lambda\left(z_{j}+x_{j}\right)}
\end{gathered}
$$


That is, the result of $\left[3 \cdot\left(\Delta w_{i}+R \theta_{i}\right)+\lambda u\right] \cdot e^{-3 \lambda\left(z_{i}+x_{i}\right)}$ is independent with $i$, so we assume $\left[3 \cdot\left(\Delta w_{i}+R \theta_{i}\right)+\lambda u\right] \cdot e^{-3 \lambda\left(z_{i}+x_{i}\right)}=a$, and let $d(\theta)=a \cdot e^{3 \lambda\left(z_{i}+x_{i}\right)}-\left[3 \cdot\left(\Delta w_{i}+R \theta_{i}\right)+\lambda u\right]$. Obviously, $\frac{\partial d}{\partial \theta_{i}}<0$, as $\theta_{i} \in[0,1]$; therefore,

$$
\left[a \cdot e^{-3 \lambda\left(\frac{u}{R}\right)}-\left(3 \Delta w_{i}+\lambda u\right)\right] \cdot\left[a \cdot e^{-3 \lambda x_{i}}-\left(3 \Delta w_{i}+3 R+3 \lambda u\right)\right] \leq 0,(i \in N)
$$

where $\theta^{0}$ satisfies $\left[3 \cdot\left(\Delta w_{i}+R \theta_{i}\right)+\lambda u\right] \cdot e^{-3 \lambda\left(z_{i}+x_{i}\right)}=a$, which is Equation (7).

Appendix A.3. Proof of Proposition 3

$$
\begin{gathered}
E\left(\Delta V_{i}(N, U, \theta)\right)=P_{i}\left(\Delta w_{i}+R \cdot \theta_{i} \cdot r_{1}\right)-C_{i} \\
P_{i}(x, \theta, N)=\frac{1}{\lambda^{N-1}} e^{-\lambda\left[-2\left(z_{i}+x_{i}\right)+\sum_{i \neq j}\left(z_{j}+x_{j}\right)+\frac{\rho}{u}\right]}
\end{gathered}
$$

and

$$
\frac{\partial P_{i}}{\partial \theta_{i}}=\frac{-2 R}{u \cdot \lambda^{N-2}} \cdot e^{-\lambda\left[-2\left(z_{i}+x_{i}\right)+\sum_{j \neq i}\left(\Delta w_{j}+R \cdot \theta_{j}\right)+\frac{\rho}{u}\right]} .
$$

Let $\frac{\partial E(V)}{\partial \theta_{i}}=0$, therefore $\frac{\partial P_{i}}{\partial \theta_{i}} \cdot\left(\Delta w_{i}+R \theta_{i} r_{1}\right)+P_{i} R r_{1}=0 \Rightarrow-2 \lambda\left(\Delta w_{i}+R \theta_{i} r_{1}\right)+r_{1} u=0$.

\begin{tabular}{|c|c|}
\hline$M$ & Number of local governments \\
\hline$N$ & Number of development zones \\
\hline$\theta_{i}$ & Tax ratio zone $i$ imposed on the total income of the new factory \\
\hline$A \cdot l^{\alpha} \cdot K^{1-\alpha}$ & Cobb-Douglas production function \\
\hline$R$ & Dominant return enterprises generate from the daily operation \\
\hline$l$ & Best labor a site investor would hire \\
\hline K & Amount of capital enterprise invested in the operation \\
\hline$w$ & Best wage the investor would offer to citizens \\
\hline$\rho$ & $\begin{array}{l}\text { Opportunity of the enterprise to build a factory outside the available } \\
\text { development zones }\end{array}$ \\
\hline$u$ & $\begin{array}{l}\text { Compatibility between the type of enterprise investment and the } \\
\text { infrastructure environment in the development zone }\end{array}$ \\
\hline$\varepsilon_{i}$ & $\begin{array}{l}\text { Compatibility between the natural resources of the zone and the } \\
\text { enterprise's expected investment environment }\end{array}$ \\
\hline$x_{i}$ & Improvement of infrastructure environment \\
\hline$C_{i}$ & Government infrastructure investment in zone development \\
\hline$V$ & Total welfare \\
\hline$P_{i}$ & Probability of the firm choosing zone $i$ \\
\hline
\end{tabular}

The best tax level is $\theta^{e}=\frac{u}{2 R \lambda}-\frac{\Delta w_{i}}{R \cdot r_{1}}$, which is Equation (9).

\section{Appendix A.4. Variable Definitions}

Variable Definitions

\section{References}

1. Caldeira, E. Yardstick competition in a federation: Theory and evidence from China. China Econ. Rev. 2012, 23, 878-897. [CrossRef] 
2. Gordon, R.; Li, W. Provincial and Local Governments in China: Fiscal Institutions and Government Behavior; National Bureau of Economic Research, Inc.: Cambridge, MA, USA, 2012; pp. 337-369. Available online: http:/ / www.nber.org/ chapters/c12075.pdf (accessed on 24 December 2017).

3. $\mathrm{Xu}, \mathrm{C}$. The fundamental institutions of China's reforms and development. J. Econ. Lit. 2011, 49, 1076-1151. [CrossRef]

4. Hatfield, J.W. Federalism, taxation, and economic growth. J. Urban Econ. 2015, 87, 114-125. [CrossRef]

5. Jin, H.; Qian, Y.; Weingast, B.R. Regional decentralization and fiscal incentives: Federalism, Chinese style. J. Public Econ. 2005, 89, 1719-1742. [CrossRef]

6. Zhang, J. Interjurisdictional competition for FDI: The case of China's "development zone fever". Reg. Sci. Urban Econ. 2011, 41, 145-159. [CrossRef]

7. Cartier, C. "Zone fever", the arable land debate, and real estate speculation: China's evolving land use regime and its geographical contradictions. J. Contemp. China 2001, 10, 445-469. [CrossRef]

8. Alder, S.; Shao, L.; Zilibotti, F. Economic reforms and industrial policy in a panel of Chinese cities. J. Econ. Growth 2016, 21, 305-349. [CrossRef]

9. Liu, Y.; Martinez-Vazquez, J. Interjurisdictional tax competition in China. J. Reg. Sci. 2014, 54, 606-628. [CrossRef]

10. Wang, J. The economic impact of special economic zones: Evidence from Chinese municipalities. J. Dev. Econ. 2013, 101, 133-147. [CrossRef]

11. Luo, D.; Liu, Y.; Wu, Y.; Zhu, X.; Jin, X. Does development zone have spillover effect in China? J. Asia Pac. Econ. 2015, 20, 489-516. [CrossRef]

12. Mayer, T.; Mayneris, F; Py, L. The Impact of Urban Enterprise Zones on Establishment Location Decisions: Evidence from French ZFUs. Banque de France. Mimeo Sciences-Po. 2013. Available online: https: //publications.banque-france.fr/sites/default/files/medias/documents/working-paper_458_2013.pdf (accessed on 24 December 2017).

13. Briant, A.; Lafourcade, M.; Schmutz, B. Can tax breaks beat geography? Lessons from the French enterprise zone experience. Am. Econ. J. Econ. Policy 2015, 7, 88-124. [CrossRef]

14. Neumark, D.; Kolko, J. Do enterprise zones create jobs? Evidence from California's enterprise zone program. J. Urban Econ. 2010, 68, 1-19. [CrossRef]

15. Kline, P.; Moretti, E. Local economic development, agglomeration economies and the big push: 100 years of evidence from the Tennessee Valley Authority. Q. J. Econ. 2014, 129, 275-331. [CrossRef]

16. Wilson, J.D. A theory of interregional tax competition. J. Urban Econ. 1986, 19, 296-315. [CrossRef]

17. Zodrow, G.R.; Mieszkowski, P. Pigou, Tiebout, property taxation, and the underprovision of local public goods. J. Urban Econ. 1986, 19, 356-370. [CrossRef]

18. Becker, J.; Schneider, A. Bidding for Firms with Unknown Characteristics; CESifo Group: Munich, Germany, 2014.

19. Durán-Cabré, J.M.; Esteller-Moré, A.; Salvadori, L. Empirical evidence on horizontal competition in tax enforcement. Int. Tax Public Financ. 2015, 22, 834-860. [CrossRef]

20. Li, Q. Fiscal decentralization and tax incentives in the developing world. Rev. Int. Political Econ. 2016, 23, 232-260. [CrossRef]

21. Besfamille, M.; Donder, P.; Lozachmeur, J.-M. The political economy of the (weak) enforcement of indirect taxes. J. Public Econ. Theory 2013, 15, 856-883. [CrossRef]

22. Zodrow, G. Capital mobility and capital tax competition. Natl. Tax J. 2010, 63, 865-901. [CrossRef]

23. Yu, J.; Zhou, L.-A.; Zhu, G. Strategic interaction in political competition: Evidence from spatial effects across Chinese cities. Reg. Sci. Urban Econ. 2016, 57, 23-37. [CrossRef]

24. Crowley, G.R.; Sobel, R.S. Does fiscal decentralization constrain Leviathan? New evidence from local property tax competition. Public Choice 2011, 149, 5. [CrossRef]

25. Delgado, F.J.; Lago-Peñas, S.; Mayor, M. On the determinants of local tax rates: New evidence from Spain. Contemp. Econ. Policy 2015, 33, 351-368. [CrossRef]

26. Buettner, T.; von Schwerin, A. Yardstick competition and partial coordination: Exploring the empirical distribution of local business tax rates. J. Econ. Behav. Organ. 2016, 124, 178-201. [CrossRef]

27. Devereux, M.P.; Lockwood, B.; Redoano, M. Do countries compete over corporate tax rates? J. Public Econ. 2008, 92, 1210-1235. [CrossRef]

28. Redoano, M. Tax competition among European countries. Does the EU matter? Eur. J. Political Econ. 2014, 34, 353-371. [CrossRef] 
29. Altshuler, R.; Goodspeed, T.J. Follow the leader? Evidence on European and US tax competition. Public Financ. Rev. 2015, 43, 485-504. [CrossRef]

30. Justman, M.; Thisse, J.-F.; van Ypersele, T. Fiscal competition and regional differentiation. Reg. Sci. Urban Econ. 2005, 35, 848-861. [CrossRef]

31. Jia, J.; Guo, Q.; Zhang, J. Fiscal decentralization and local expenditure policy in China. China Econ. Rev. 2014, 28, 107-122. [CrossRef]

32. Chen, Z.; Tang, J.; Wan, J.; Chen, Y. Promotion incentives for local officials and the expansion of urban construction land in China: Using the Yangtze River Delta as a case study. Land Use Policy 2017, 63, 214-225. [CrossRef]

33. Ding, C.; Lichtenberg, E. Land and urban economic growth in China. J. Reg. Sci. 2011, 51, 299-317. [CrossRef]

34. Yang, D.Y.-R.; Wang, H.-K. Dilemmas of local governance under the development zone fever in China: A case study of the Suzhou region. Urban Stud. 2008, 45, 1037-1054. [CrossRef]

35. Gallouj, C.; Gallouj, F. Services in regional development policies: The French case. In Service Industries and Regions: Growth, Location and Regional Effects; Cuadrado-Roura, J.R., Ed.; Springer: Berlin/Heidelberg, Germany, 2013; pp. 425-447.

36. Bessho, S.-I.; Terai, K. Competition for private capital and central grants: The case of Japanese industrial parks. Econ. Gov. 2011, 12, 135-154. [CrossRef]

37. Becker, J.; Davies, R. Learning to Tax?-Interjurisdictional Tax Competition under Incomplete Information; School of Economics, University College Dublin: Dublin, Ireland, 2015.

38. Huang, Z.; He, C.; Zhu, S. Do China's economic development zones improve land use efficiency? The effects of selection, factor accumulation and agglomeration. Landsc. Urban Plan. 2017, 162, 145-156. [CrossRef]

39. Jimenez, B.S. Separate, unequal, and ignored? Interjurisdictional competition and the budgetary choices of poor and affluent municipalities. Public Adm. Rev. 2014, 74, 246-257. [CrossRef]

40. King, I.; McAfee, R.; Welling, L. Industrial Blackmail of Local Governments; California Institute of Technology, Division of the Humanities and Social Sciences: Pasadena, LA, USA, 1990.

41. Jayet, H.; Paty, S. Capital indivisibility and tax competition: Are there too many business areas when some of them are empty? J. Urban Econ. 2006, 60, 399-417. [CrossRef]

42. Philipowski, R. Comparison of Nash and evolutionary stable equilibrium in asymmetric tax competition. Reg. Sci. Urban Econ. 2015, 51, 7-13. [CrossRef]

43. Aslim, E.G.; Neyapti, B. Optimal fiscal decentralization: Redistribution and welfare implications. Econ. Model. 2017, 61, 224-234. [CrossRef]

(C) 2018 by the authors. Licensee MDPI, Basel, Switzerland. This article is an open access article distributed under the terms and conditions of the Creative Commons Attribution (CC BY) license (http://creativecommons.org/licenses/by/4.0/). 